\title{
Tradição e controle normativo das práticas musicais: uma análise dos paradigmas romanos e seu impacto na música católica no Brasil entre 1903 e 1963
}

Tradition and normative control of musical practices: an analysis of Roman paradigms and their impact on Catholic music in Brazil between 1903 and 1963

Tradición y control normativo de las prácticas musicales: un análisis de los paradigmas romanos y su impacto en la música católica en Brasil entre 1903 y 1963

Fernando Lacerda Simões Duarte

\section{Resumo}

Compositores de música religiosa têm diante de si diversas possibilidades de assimilação de elementos musicais em seu processo criativo. $\mathrm{O}$ mesmo ocorre em relação à seleção de obras pelos intérpretes. Este trabalho analisa os paradigmas instituídos pelo motu proprio sobre a música sacra de Pio $X$, promulgado em 1903, e seus reflexos nas práticas de música religiosa no Brasil entre 1903 e 1963. Para tanto, recorre-se às noções de habitus, em Pierre Bourdieu, dos tipos weberianos de dominação, em Walter Buckley, e de modelo pré-composicional (MPC), em Sotuyo Blanco. Os resultados apontam para a existência de uma expectativa de controle institucional do tipo racional-legal, inclusive com organismos censores. Pouco compatível com as noções de habitus ou MPC, tal fenômeno demanda o desenvolvimento de um conceito específico, o de controle normativo das práticas musicais.

Palavras-chave: Controle normativo das práticas musicais. Motu proprio "Tra le Sollecitudini". Música litúrgica na Igreja Católica Romana. Romanização.

Pós-doutorando com bolsa PNPD/Capes pelo Programa de Pós-Graduação em Artes da Universidade Federal do Pará.

E-mail: lacerda.lacerda.lacerda@gmail.com

Recebido em 28/8/2017 - Aprovado em 12/9/2017 http://dx.doi.org/10.5335/hdtv.18n.1.7258 


\section{Introducão}

Ao longo da história da Igreja Católica Romana, a disciplina das práticas musicais em seus templos se deu por meio de diversos mecanismos e estabeleceu metas distintas em diferentes períodos. Da relação de subserviência da música ao texto cantado defendida por Santo Agostinho no século V à inserção de ritmos brasileiros nos cantos litúrgicos autóctones na década de 1970, o controle eclesiástico sobre a atividade musical variou não somente no tocante à forma - discursos, estudos, normas, tradição e outros -, mas também no grau de detalhamento das prescrições. Até o século XX, nenhum documento se ocupou com tamanha especificidade da atividade musical de caráter litúrgico quanto o motu proprio "Tra le Sollecitudini" de Pio X, de 22 de novembro de 1903, objeto do presente estudo. Sua rígida definição de paradigmas se insere em um processo de mudanças mais amplo pelo qual passou o catolicismo romano, cujas causas remetem a fins do século XIX. Trata-se da passagem do catolicismo iluminista à autocompreensão conhecida como Romanização, que buscou o fortalecimento institucional por meio do reforço ao senso de hierarquia clerical e da centralização das atividades religiosas nas figuras dos clérigos (WERNET, 1987). No campo da música, é possível observar a passagem de uma concepção de música próxima do Iluminismo - na qual as fornteiras entre a música praticada nos teatros e aquela das igrejas era minimizada - ao Cecilianismo, movimento de acadêmicos e especialistas que buscava restaurar a música litúrgica a uma suposta condição de dignidade nos ritos por meio do resgate do repertório do passado e da criação de uma música moderna adequada aos templos.

A introdução do motu proprio de Pio $\mathrm{X}^{1}$ foi dedicada à condenação da influência da arte teatral (ópera) sobre a música eclesiástica e se refere a uma sociedade musical, florescente em Roma, que se dedicava à restauração da dignidade do gênero sacro, a academia de Santa Cecília. Dentre as diversas vias para a restauração musical católica que foram expressas nos discursos dos acadêmicos e especialistas do Cecilianismo, o resgate do passado era um deles e certamente se refletiu no motu proprio de Pio X: o canto gregoriano foi declarado o gênero musical oficial da Igreja e foi incentivada com o mesmo interesse a música italiana para coro do século XVI, particularmente as obras de Giovanni Pierluigi da Palestrina (1525-1594). O nome de Palestrina esteve associado, ao longo de séculos, ao Concílio de Trento e à Contrarreforma, razão pela qual sua obra serviria como modelo e reforço ideológico para uma nova reação do catolicismo aos vícios observados no campo da música. Assim, a música coral moderna seria tão mais santa quanto se aproximasse dos referenciais do passado (canto gregoriano e música polifônica do século XVI) e se afastasse, consequentemente, das músicas praticadas nos teatros. Recorrendo a Joël Candau (2011), é possível afirmar que no século XX, o sistema religioso passou em antigas memórias a constituição de uma nova identidade musical.

A fim de evitar quaisquer divergências entre os modelos oficiais e a música que passaria a ser produzida para os templos - a chamada polifonia moderna ou repertório restaurista -, Pio X precisou de considerável 
aprofundamento ao especificar parâmetros dessa música: ela nada poderia ter de profano no andamento, nos motivos musicais (melodias vocais sem virtuosismos e ornamentação) e deveriam guardar o convencionalismo inerente à música eclesiástica. $\mathrm{O}$ texto litúrgico deveria ser cantado em língua latina, conforme escrito nos livros litúrgicos aprovados pela Igreja. Quanto aos cantores, a fim de garantir a moralidade e respeitar o "verdadeiro Ofício litúrgico" dessa função nas celebrações", as mulheres não eram admitidas nos coros, exceto em coros de conventos. No lugar dos coros mistos, vozes meninos (pueri cantorum) deveriam substituir as femininas. O órgão foi declarado instrumento oficial da Igreja, sendo tolerados os instrumentos de cordas friccionadas (violino, viola, violoncelo e contrabaixo) e, a critério da autoridade eclesiástica local, os instrumentos de sopros, desde que guardassem o caráter grave do acompanhamento do órgão. O caráter grave se caracterizaria pela sustentação do canto, ou seja, pela reprodução, no instrumento, das melodias vocais ${ }^{3}$, não havendo clara distinção entre a música instrumental e a vocal, como era inerente às óperas e às canções populares. Por essa razão, ao defender e propagandear as disposições do motu proprio, Basílio Röwer (1907) se referiu a uma maneira identitária de execução instrumental que diferenciaria sua execução do modo de tocar o piano, que fora proibido nas igrejas pelo motu proprio. Além do piano, a proibição recaía sobre os instrumentos de percussão e sobre as bandas de música. Como se observa, as disposições do documento de Pio $X$ não se limitavam a aspectos composicionais, mas se estendiam também a aspectos interpretativos.
Finalmente, Pio $\mathrm{X}$ cuidou de apresentar distintos gêneros de música sacra, associando-os a distintos graus de importância no culto católico. O maior deles, o canto gregoriano poderia ser empregado sozinho em toda a celebração. Em segundo lugar, mas igualmente incentivada, a polifonia clássica dos compositores tridentinos - sobretudo a de Palestrina - deveria ser executada pelas scholae cantorum. A polifonia moderna ou repertório restaurista também recebeu incentivo, desde que nada guardasse de profano ou teatral. Finalmente, os cantos religiosos populares ou cânticos espirituais foram mencionados no motu proprio no acompanhamento de procissões. Em uma análise de outras publicações do período se percebe, entretanto, que tais cânticos de melodia simples e fácil assimilação, executados na língua vernácula eram admitidos em todas as funções não solenes, o que incluiria as missas rezadas que se realizavam fora das grandes festividades do calendário litúrgico (SCHUBERT, 1980; INAMA, LESS, 1892, p. 192-209). A pesquisa em acervos musicais revelou o amplo uso de tais cânticos em língua vernácula, que já circulavam de maneira sistematizada no Brasil, pelo menos desde meados do século XIX (DUARTE, 2016).

Apresenta-se neste trabalho um breve panorama dessas causas que conduziram à institucionalização do catolicismo, a partir de fins do século XIX, e particularmente, de sua música, objetivando responder os seguintes problemas: as relações de controle envolvidas na disciplina da música sacra católica a partir do motu proprio de Pio X apresentam aspectos distintos dos séculos anteriores a ponto de caracterizar a passagem do tipo weberiano tradicional para o racional- 
-legal? Se sim, considerando a necessidade de clareza, univocidade e objetividade dos conceitos científicos, as noções - discutidas mais adiante - de habitus, em Pierre Bourdieu ou de modelo pré-composicional, em Sotuyo Blanco (2003) seriam suficientes para explicar esta nova forma de dominação ou seria necessário propor um novo conceito, que a reflita de maneira mais clara? A fim de obter respostas, procedeu-se à investigação bibliográfica e documental, considerando-se documento inclusive fontes propriamente musicais, tais como as partituras. Fontes musicais recolhidas a acervos eclesiásticos, públicos e de particulares foram discutidas, entretanto, com maior vagar em investigação de doutorado sobre os resgates e abandonos de passados na prática musical litúrgica católica no Brasil no século XX. No presente trabalho, os documentos eclesiásticos que nortearam a prática musical tiveram maior destaque, sendo as fontes musicais - que serviram para o confronto entre as normas e a realidade - citadas por meio dos dados obtidos na referida tese (DUARTE, 2016).

Para a análise dos documentos eclesiásticos, das relações de controle inerentes ao catolicismo no momento em que foram produzidos, bem como das conjunturas que conduziram a tais relações, recorreu-se à abordagem sistêmica de Niklas Luhmann (1995), por meio da qual um sistema religioso - ou qualquer sistema social - pode ser considerado aberto (em contato com o entorno), mas operacionalmente fechado, a fim de resguardar sua identidade. Diante dos estímulos provenientes do entorno - no caso da Igreja Católica, de suas relações com o poder temporal, mas também da diversidade interna de opiniões de indivíduos que a integram em diferentes meios -, o sistema pode aceitá-los e se modificar, adaptando-se à nova situação ou se manter fechado a fim de preservar sua identidade. Walter Buckley (1971) procurou adequar à abordagem sistêmica - há muito corrente na Sociologia - aos tipos weberianos de relações de controle (carismático, tradicional e racional-legal), fazendo distinção, entretanto, entre relações de poder e autoridade: no primeiro caso, as relações beneficiariam apenas parte dos indivíduos que integram o sistema e, no segundo, beneficiariam igualmente a todos, sendo mais legítimas, portanto, a partir de uma perspectiva democrática.

Busca-se compreender, dessa manei$\mathrm{ra}$, as estruturas sobre as quais se fundam o controle da música católica de uso litúrgico anterior ao Concílio Vaticano II (1962-1965) e os possíveis desdobramentos teóricos daí decorrentes. O trabalho parte de um olhar abrangente lançado ao sistema religioso e seu entorno, em seguida analisa os mecanismos de controle do motu proprio de Pio $\mathrm{X}$ e retoma a questão da música litúrgica discutida a partir dos conceitos de habitus e de modelo pré-composicional, a fim de analisar a aplicabilidade dos referidos conceitos ao período estudado ou desenvolver outro que se revele mais adequado.

\section{Romanizacão e controle}

Eamon Duffy destacou uma série de reformas administrativas desenvolvidas no pontificado de Pio $X$ e de seus sucessores com vistas a uma maior eficiência administrativa e pastoral, dentre as quais a reforma do Código de Direito Canônico - que só seria concluída três anos após a morte de Pio 
X. Este código "deveu mais ao espírito do Código de Napoleão que às Escrituras ou à tradição patrística [...] e consagrou como características da Igreja aspectos do ofício papal que eram desenvolvimentos muito recentes" (DUFFY, 1998, p. 247). Em outras palavras, o espírito da Romanização movia as bases das relações de controle da tradição para a norma. Esse direito aparentemente transcendente se legitimava, desde o Concílio Vaticano I - realizado em 1870 - pela infalibilidade papal, estruturando uma cadeia de normas que provinham do pontífice romano, de sua Cúria e chegava às realidades locais também por meio de sínodos e cartas episcopais. Se a hierarquia era há séculos representada pelos chapéus de borlas das insígnias dos clérigos, o caráter de centralização em Roma e de obediência àquele que estaria além das montanhas - oltra monti - garantiriam à Igreja Católica a unidade pretendida como resposta às mudanças em suas relações com o entorno a partir da segunda metade do século XIX: separação dos estados nacionais, casamento civil leis de divórcio, ensino estatal, perda do foro privilegiado de clérigos, expulsão de ordens religiosas, espoliação de bens, dentre outros fatos.

Segundo Augustin Wernet (1987), a Romanização objetivava a moralização e instrução do clero, o reforço à hierarquia eclesiástica, a centralização das celebrações na figura do clérigo - não mais no serviço dos leigos que promoviam, no Brasil, as atividades e festas religiosas de irmandades e ordens terceiras -, além do envio de missionários de origem europeia com a missão de difundir os ideais da autocompreensão ul- tramontana do catolicismo. Estas metas geraram uma padronização das manifestações religiosas:

Engendrado com a mesma concepção medieval unitária do Universo, esse catolicismo estava marcado pelo centralismo institucional em Roma, por um fechamento sobre si mesmo e por uma recusa de contato com o mundo moderno. [...] Com uma rigidez hierárquica, reproduzida também pelas mais distantes células paroquiais, o ordenamento ultramontano aspirava a uma univocidade entre a Europa, Ásia, África e América. [...]

Nesse sonho unitário não se configuravam as incompatibilidades e as alteridades identitárias. Na busca do uno, diante do múltiplo social, manifestava-se a intransigência ante o plural, confrontando-se, na verdade, com o próprio lugar da história que é, por excelência, o lugar da divisão e dos choques de valores. De maneira análoga à sociedade das abelhas, afastava-se a diversidade [...] (GAETA, 1997, p. 195).

Com base nesse pensamento, o pontificado de Pio X - e também de alguns de seus sucessores - se tornara absolutamente centralizador, passando necessariamente por sua análise pessoal os antecedentes de todos aqueles que haveriam de ser nomeados bispos, o que Duffy (1998, p. 248) chamou de "reforma ao estilo tridentino". O passado servia, portanto, como elemento de legitimação para mecanismos de controle institucionais mais centralizadores e, portanto, na visão ultramontana, mais eficientes.

Numa sequência de papados que se opuseram duramente ao comunismo e até mesmo às tendências liberais, as associações de leigos deveriam ser estritamente confessionais, sem caráter político ou de sindicato e, principalmente, obedecer em tudo à 
direção clerical. Qualquer abertura cognitiva (LUHMANN, 1995) a novas correntes de pensamento teológico foi impossibilitada graças ao "Jurmento Antimodernista" que os postulantes ao sacerdócio e mesmo às carreiras de vulto na hierarquia católica deveriam prestar. Nesse ambiente de hostilidade a tudo o que fosse secular, a política diplomática de Pio $X$ pode ser considerada desastrosa, pois seu posicionamento "profético" ante os vícios da modernidade o levava a "confutar e repelir as leis seculares" (DUFFY, 1998, p. 251).

Diante desse cenário, vale recorrer às características da administração do tipo burocrática, inerente à dominação racional-legal webweriana. Idalberto Chiavenato (2005) apontou como principais características dessa forma de gestão a impessoalidade, o papel estruturante das normas, a hierarquia verticalizada, a padronização de comportamentos e rotinas e o caráter formal da comunicação. A aplicação deste modelo em indústrias resultou na padronização dos produtos, ou seja, da produção em série. A padronização do catolicismo contou com a cooperação do poder secular, até mesmo com a intervenção da polícia na coibição de manifestações do catolicismo popular.

Apesar da devolução do Padroado, os interesses do poder religioso e do civil ainda convergiam em diversos pontos: o poder temporal atendia às expectativas do clero e a Igreja cooperava num processo civilizador de moldes europeus. Em Goiás, por exemplo, o jornal católico O lidador - órgão de imprensa oficial da diocese - prescrevia aos fieis uma série de Mandamentos da Hygiene ${ }^{4}$, além de trajos e costumes a serem conservados em lo- cais públicos ${ }^{5}$. Havia, portanto, um processo de realimentação: de um lado, a Belle époque taxava os costumes do passado colonial de atrasados e contrários ao progresso, ao passo assimilava modelos europeus; de outro, o catolicismo institucionalizado de feições europeias se adequava a tais expectativas, pois não tinha mais os rituais e "crendices" populares, reinantes nos tempos de colônia. Assim, a identidade religiosa criada pela autocompreensão romanizada ia ao encontro das expectativas de parte da sociedade que se pretendia civilizar aos moldes europeus, ao mesmo tempo em que excluía os que não se adequassem a esta nova realidade. Não é de se estranhar, portanto, o crescimento de outras religiões - sobretudo da umbanda e do baixo espiritismo (ORTIZ, 1999) - entre o contingente de excluídos: escravos alforriados, ex-combatentes de guerra e moradores dos cortiços: a população que de algum modo se ligava a um passado colonial que a crença no progresso material e civilizatório buscava apagar ficara às margens da cidade (processos de reurbanização), da chamada alta cultura e das manifestações musicais eruditas, sujeitava-se às ações higienistas $\mathrm{e}$ até mesmo suas tradições religiosas católicas viram-se silenciadas por força do catolicismo institucional ultramontano.

Em lugar das tradições locais, por meio das quais se transmitiam as memórias religiosas e musicais mais profundas -, a autocompreensão romanizadora buscou instituir uma tradição única, portadora de grandes memórias organizadoras (CANDAU, 2011) e, portanto, inquestionável, pois se legitimaria tanto pela transcendência, quanto por força de normas. Nesse cenário, as di- 
versidades culturais e de manifestações da religiosidade deveriam ser niveladas pela estandardização de comportamentos e de formas externas do culto católico, do mesmo modo que as práticas musicais particulares o foram por meio da restauração musical de bases acadêmicas europeias.

\section{Motu proprio:histórico, mecanismos de controle e a realidade}

As disposições do motu proprio não decorreram de convicções pessoais de Pio X, mas refletem o compartilhamento de uma noção de decadência que havia se instalado entre músicos práticos e tratadistas (teóricos da música) desde o século XVIII. Essa sensação passou a ser compartilhada de maneira mais intensa no século XIX, na medida em que as características da ópera e da música sinfônica se faziam ouvir cada vez mais dentro dos templos. Tal era essa situação, que em algumas localidades os textos de árias de ópera chegaram a ser substituídos por aqueles da missa para que soassem dentro dos templos. Contra esses abusos, se insurgiram acadêmicos e especialistas em música religiosa - muitos dos quais compositores - que se reuniam na Associação de Santa Cecília alemã, que foi reconhecida por Pio IX em 1868. No mesmo ano, a associação passara a publicar um periódico - existente até hoje sobre música sacra, no qual se discutia a realidade observada e as possíveis alternativas para uma restauração. A publicação do periódico cecilianista na cidade alemã de Regensburg (Rastibona) acabou por atrair para essa cidade a publicação de grande parte do repertório restaurista de finais de século XIX e do XX.

Longe da transmissão de uma memória musical por meio de partituras manuscritas, a publicação impressa possibilitava maior controle das autoridades eclesiásticas do repertório a ser executado. Assim, a casa publicadora Pustet de Regensburg antecipava, no século XIX, a universalidade e estandardização inerentes às disposições do motu proprio, quando ainda se discutiam as diretrizes que culminariam em tal documento. Frei Pedro Sinzig, franciscano defensor da Resturação musical católica publicava pela casa Pustet, em 1899, uma coletânea de cantos religiosos populares - em latim e vernáculo - para uso no Brasil, Benedicte.

Já no século $X X$, a promulgação do motu proprio foi repercutida em jornais brasileiros apontando para esforços na difusão de seus ideais: no jornal Correio do Povo (1904), de Florianópolis, a publicação data de fevereiro de 1904, menos de três meses após a publicação em Roma ${ }^{6}$. Também se tem notícia de uma publicação em Mariana-MG no mesmo ano. Ademais, merece destaque o livro de frei Basílio Röwer (1907) no qual o motu proprio foi traduzido integralmente e teve parágrafo comentado, com forte apologia e defesa dos ideais restauristas. Destaca-se ainda como o periódico Musica sacra, publicado na cidade São Paulo pelo maestro italiano Furio Franceschini, uma coletânea de músicas para uso litúrgico que o compositor italiano considerava adequadas ao culto católico, a partir das prescrições do motu proprio (DUARTE, 2012). Além da propaganda, a composição de música coral por Franceschini, Sinzig, Röwer e outros foi fun- 
damental para a difusão dos ideais do motu proprio. Além de centenas de missas 7 , numerosas coletâneas de cantos foram publicadas na primeira metade do século $X X$, dentre as quais se destaca como a mais recorrente nos acervos brasileiros visitados, a Harpa de Sião, publicada por João Batista Lehmann (1928). Tal é sua recorrência que seria possível afirmar que essa coletânea é o exemplo máximo da restauração musical no Brasil.

Outra via encontrada por Pio X para inculcar os referenciais de seu motu proprio foi estimular a criação das scholae cantorum exclusivamente de clérigos e outras paroquiais. Além disso, nos seminários deveria haver aulas de música e arte sacras, trazendo assim, para a identidade dos clérigos em formação - por meio da protomemória, ou seja, uma assimilação pela repetição (CANDAU, 2011) -, os ideais restauristas. Ainda, criação de associações de Santa Cecília ou de São Gregório Magno - fundadas com as mesmas finalidades - foi recorrente em diversos países europeus.

Todos os meios até então mencionados já seriam fortes indícios para a comprovação de uma mudança nas relações de controle da música sacra católica, mas o argumento definitivo foi dado pelo próprio Pio $X$ na introdução do documento: o motu proprio deveria funcionar como um "código jurídico de música sacra". Não mais a tradição, os critérios da autoridade religiosa local e, principalmente, a relação entre os fiéis e o repertório determinariam sua adequação ao culto, mas a força de uma norma. Essa norma não somente imporia memórias, mas principalmente decretaria esquecimentos de memórias musicais. Longe de se ligar às ne- cessidades e gostos do presente, a memória musical passaria a ser legitimada por grandes memórias organizadoras (um repertório oficial, um instrumento musical oficial e a grande música do passado tridentino), ao mesmo tempo em que colaboraria para legitimar, na liturgia, os ideais de unidade da Romanização. Desse modo, o repertório restaurista revela, além da funcionalidade ritual que lhe é inerente, uma funcionalidade ideológica, a serviço do estabelecimento de uma nova identidade católica. Mais do que um processo natural de transmissão da memória e manutenção de um repertório na prática musical, o resgate intencional do repertório do século XVI se daria por força das normas da Cúria Romana, remetendo a relações de controle do tipo racional-legal e não à dominação tradicional. Cabia, portanto, à memória legitimar a passagem das relações do tipo tradicional às do tipo racional-legal no interior do catolicismo.

Se o documento de Pio $X$ deveria ser considerado um "código jurídico", sua aplicabilidade também deveria se assemelhar à das normas jurídicas: para além do prescritivo dos paradigmas estabelecidos - que se observou na introdução deste trabalho -, deveria haver um mecanismo real de controle real, diferenciando a norma de simples preceitos morais. A coerção e a coercitividade possibilidades abstratas de coerção em caso de desrespeito - são características de normas jurídicas e, portanto, de um controle racional-legal (REALE, 2001). A fim de garantir o controle da produção e prática musicais católicas, o motu proprio determinava que se criassem nas dioceses comissões de música sacra constituídas por peritos no assunto ${ }^{8}$. A 
essas comissões caberia a função de censura, ou seja, de julgar as obras musicais quanto à sua adequação às normas e exarar pareceres, fundamentando a decisão de aprová-las ou não. Caso aprovadas, as partituras trariam, na contracapa, o imprimatur, ou seja, a autorização para que se imprimisse - também registrado sob a fórmula "Nihi obstat" - e a assinatura de uma autoridade religiosa. Se reprovada, além da recomendação de proibição nas paróquias, foi criado, no Rio de Janeiro, um index de obras adequadas ou reprovadas, o $1^{\circ}$ Índice das Músicas Examinadas para uso litúrgico pela Comissão Arquidiocesana de Música Sacra do Rio de Janeiro. ${ }^{9}$ Frei Pedro Sinzig, presidente da comissão do Rio de Janeiro editou, a partir de 1941, o periódico Música Sacra, cujos volumes constavam de uma de com uma obra selecionada que estivesse de acordo com os paradigmas composicionais do motu proprio (propaganda), artigos teóricos e notícias. No periódico, era discutida, em suma, a situação da música sacra no país, com notícias das mais remotas localidades. Além disso, Música Sacra trazia os pareceres da Comissão Arquidiocesana de Música Sacra do Rio de Janeiro, tanto os de aprovação quanto os de recusa. Diante desse quadro, fica claro que existiam não somente mecanismos para promover a difusão dos ideais da restauração da música sacra, mas também órgãos censores capazes de controlar a circulação das obras julgadas em desacordo com esses ideais. A forma manuscrita que até então caracterizava a circulação de música sacra no Brasil em tempos de colônia passava a ceder lugar às obras impressas, estas últimas, passíveis de um controle eclesiástico mais direto. Em suma, as relações de produção, execução e circulação do tipo tradicional que caracterizavam a prática musical religiosa no Brasil colonial cedeu espaço gradativamente para um modelo estruturado sobre bases normativas, passível de classificação, portanto, no subtipo weberiano racional-legal ou institucionalizado.

Uma sessão intitulada jus musicae liturgicae na biblioteca particular do compositor Furio Franceschini - recolhida hoje à Biblioteca do Instituto de Artes da Unesp - ilustra a relevância das normas no estabelecimento e o controle das práticas musicais. A publicação de coletâneas de normas sobre música sacra, tanto com normas papais, quanto com instruções e respostas ${ }^{10}$ provenientes da Sagrada Congregação dos Ritos foi corrente na primeira metade do século XX (DUARTE, 2012). O controle racional-legal da música litúrgica não parece ter sido, entretanto, um evento isolado, mas resultado do processo de próprio da Romanização.

\section{Estruturas determinantes e liberdade de opção dos compositores}

Se a música religiosa colonial foi marcada por espíritos de época que conjungavam tradições musicais locais e inovações provenientes da Europa, num panorama dentro do qual os compositores fariam suas opções, no século XX, os paradigmas musicais da música tolerada pelo sistema religioso eram bastante claros: nada poderiam ter de profano ou teatral e deveriam se adequar a uma série de exigências relativas à construção das melodias vocais, elaboração do acompanhamento instrumental e guardar 
uma relação com o grande passado musical católico, a polifonia da Contrarreforma e o canto gregoriano.

Ao tratar os modos pelos quais se estabeleceram paradigmas para as composições musicais, George Perle desenvolveu o conceito de modelo pré-composicional, que foi introduzido em trabalhos da área de musicologia no Brasil por Pablo Sotuyo Blanco:

Um modelo é (entre as diversas definições possíveis) tanto um objeto destinado a ser reproduzido por imitação, quanto aquilo que serve de exemplo ou norma: um molde. Por sua vez, o termo pré-composicional refere (como já indicava George Perle quando o utilizou em 1962) àquilo que é anterior à composição.

Modelo Pré-Composicional (em diante MPC) se define aqui como o conjunto de princípios e/ou fatores que condicionam $a$ priori - explícita ou implicitamente, voluntária ou involuntariamente, consciente ou inconscientemente - o produto composicional (a obra musical) em algum dos seus aspectos.

$\mathrm{O}$ referido conjunto de princípios e/ou fatores pode vir tanto da tradição oral como da tradição escrita, podendo tanto se manter ou se modificar, isto é, interagindo entre si no criador, para refletir, de alguma forma, no produto composicional (SOTUYO BLANCO, 2003, p. 7).

Como se observa, a noção de modelo pré-composicional privilegia a transmissão pela via tradicional, ou o que Candau (2011) chamou de didatismo genuíno, ou seja, a transmissão de memórias ou protomemórias diretamente ligadas às necessidades dos indivíduos no presente. Desse modo, não há de se falar no estabelecimento de grandes memórias organizadoras com o objetivo de legitimar mudanças estruturais nas relações de controle da prática musical, nem tampou- co de um controle baseado em prescrições e proibições, passível de censura por órgãos criados com essa finalidade. Ao contrário, o conceito modelo pré-composicional insinua a liberdade do compositor ao optar por aderir ou não aos modelos ao tratar da adesão voluntária. Nesse sentido, se aproximaria da noção de habitus em Bourdieu:

O conceito de habitus seria assim a ponte, a mediação, entre as dimensões objetiva e subjetiva do mundo, ou simplesmente, entre a estrutura e a prática. $\mathrm{O}$ argumento de Bourdieu é o de que a estruturação das práticas sociais não é um processo que se faça mecanicamente, de fora para dentro, de acordo com as condições objetivas presentes em determinado espaço ou situação social. Não seria, por outro lado, um processo condicionado de forma autônoma, consciente e deliberada pelos sujeitos individuais. As práticas sociais seriam estruturadas, isto é, apresentariam propriedades típicas da posição social de quem as produz, porque a própria subjetividade dos indivíduos, sua forma de perceber e apreciar o mundo, suas preferências, seus gostos, suas aspirações estariam previamente estruturadas em relação ao momento da ação (NOGUEIRA, 2006, p. 29).

Um exemplo de modelo pré-composicional se observa, por exemplo, em determinados padrões de instrumentação musical, que refletia a disponibilidade de instrumentistas e instrumentos existentes no período e das possibilidades técnicas desses instrumentos, ou seja, eram estruturas que condicionavam a atuação do compositor, mas ainda assim lhe possibilitavam um rol bastante amplo de opções. Observa-se, portanto, um condicionamento a priori das composições, mas com um controle posterior pautado tão somente pela aceitação do próprio compo- 
sitor e de seu público. Diante da existência de organismos censores, como foi o caso das comissões diocesanas de música sacra, a aceitação da obra era condicionada por um julgamento externo de adequação daquele produto aos paradigmas de uma norma.

Weber apontou para o risco de uma jaula de ferro existente nas relações de controle do tipo racional-legal ou institucionalizado, ou seja, para a maior dificuldade de se introduzirem mudanças graças, justamente, ao rígido estabelecimento de padrões. Em outras palavras, a padronização gerada pelo modelo burocrático-institucional conduz com facilidade à produção em massa que caracteriza a era industrial: objetos considerados fora do padrão são descartados e substituídos por outros ou têm seu valor econômico depreciado. No caso da música, longe do compartilhamento voluntário de uma estrutura, tradição musical local ou habitus, se observa no controle por meio de normas uma aceitação da obra condicionada à adesão às normas. Guardadas as devidas proporções em relação à produção industrial, pautada pelo sistema racional-legal weberiano, algumas características comuns da aplicação dos paradigmas do motu proprio ao repertório restaurista permitem identificar essse último como padronizado: a sustentação das vozes pelo acompanhamento, o uso de temas musicais extraídos do canto gregoriano, a ligação com modelos musicais do passado, a ambiguidade entre modos eclesiásticos e escalas da música tonal ${ }^{11}$, o uso recorrente de falsobordões ${ }^{12}$ - esses dois últimos, ensejados pelas pesquisas que ocorriam na Europa, no século XIX, sobre a paleografia do canto gregoriano -, dentre outras.
Sotuyo Blanco (2003) tentou solucionar o impasse entre os tipos de controle que fundam as relações de produção musical tratando do modelo pré-composicional dogmático e pragmático ao tratar dos repertórios musicais litúrgico e paralitúrgico católicos. Esses subtipos parecem dar conta da funcionalidade de tais repertórios, mas se revelam limitados do ponto de vista do controle efetivo, pois a disciplina da música "oficial" (litúrgica) sofreu as mudanças aqui destacadas somente no início do século XX. Se por um lado a Igreja Católica produziu paradigmas em normas anteriores ao século XX - como foi o caso da Encíclica "Annus qui", de Bento XIV, de 1749 -, fato é que o grau de liberdade conferido àqueles envolvidos na produção e prática musicais era consideravelmente maior, seja pela menor especificidade dos modelos, seja pela ausência dos órgãos censores. Assim, a noção de modelo pré-composicional não parece suficiente para descrever o fenômeno de controle das práticas musicais a partir do motu proprio "Tra le Sollecitudini". Dessa maneira, apresenta-se como alternativa a noção de controle normativo, baseada nas relações do tipo racional-legal:

O controle normativo das práticas musicais católicas posteriormente ao motu proprio "Tra le Sollecitudini" consiste, deta maneira, na determinação de modelos por meio de normas objetivas - detalhistas, específicas, prescritivas ou proibitivas -, com vistas à uniformização e conformação das práticas às metas institucionais. Para tanto, a criação e a execução da música foram controladas por órgãos específicos, tornando-se passí- 
veis de sanção, em caso de descumprimento, e de propaganda, em caso de adequação.

Diante de tais mecanismos de controle do tipo racional-legal, cabe questionar qual o grau de liberdade encontrado pelos indivíduos que praticavam música nos templos católicos. Em outras palavras, questiona-se até que ponto todos esses mecanismos garantiram a unidade musical esperada. A resposta converge para a afirmação de Samyra Brollo:

A difusão de um documento papal não se realiza de modo neutro ou imediato. Ela depende, ao mesmo tempo, do conjunto de interpretações que se sobrepõem ao texto inicial e da maior ou menor capacidade de mobilização prática e financeira de que dispõem os grupos que deverão articular sua defesa ou sua crítica (MONTERO, 1992, p. 91).

Nesse complexo quadro de difusão das normas eclesiásticas, fontes musicais recolhidas a acervos eclesiásticos particulares revelaram a manutenção de obras que poderiam ser consideradas inadequadas pelo motu proprio - e o foram, em muitos pareceres das comissões de música sacra - em diversas localidades. Dentre esses compositores, estavam Jacques Louis Battmann (1818-1886) e Luigi Bordèse (1815-1886), absolutamente recorrentes em fontes recolhidas aos acervos brasileiros, mas reiteradamente condenados pelas comissões de música sacra. Não se observou, entretanto, um caráter de oposição em relação àquelas consideradas adequadas, mas muitas vezes de convivência, revelando que o controle - por mais que fosse aparatado de meios que o visassem à sua eficiência não conseguiu limitar completamente as liberdades individuais. Além das negociações no plano da seleção do repertório dessa comunidade, foi possível observar que diversos compositores - inclusive integrantes do clero - mantiveram uma linguagem musical que representou uma negociação em relação às normas: se não construíam melodias de caráter operístico, muitas vezes escreviam o acompanhamento instrumental se valendo de uma escritura instrumental própria do piano, e não do órgão. Observa-se dessa maneira que a existência de um sofisticado mecanismo de controle não foi suficiente para limitar integralmente a atuação dos sujeitos, revelando a existência mais de uma expectativa de controle do que de controle efetivo das práticas musicais (DUARTE, 2016).

\section{Considerações finais}

Como resposta à problemática formulada neste trabalho, foi possível observar a passagem de uma situação em que o habitus ou as tradições locais determinavam os paradigmas da produção e prática musicais a uma relação de dominação do tipo racional-legal. Esta forma de controle não somente implicava o cerceamento a priori de possibilidades franqueadas ao compositor, mas também a necessidade de uma adesão compulsória às normas, sob pena de recusa de sua obra. O alto grau de detalhamento dos paradigmas composicionais por pio $\mathrm{X}$ e as comissões de música sacra - formadas por peritos encarregados da análise da conformação das composições às prescrições da norma - constituíram os principais fatores distintivos entre as práticas musicais baseadas em modelos pré-composicionais e essa nova situação, de controle normativo com- 
posicional e interpretativo. Dessa maneira, muito mais do que a determinação de um modelo pré-composicional ou de um habitus que condicionasse as opções individuais na criação e execução de obras musicais, existiu efetivamente uma expectativa de controle normativo, já que, em diversas dioceses do Brasil, as fontes musicais revelam que a tradição musical e até mesmo o desconhecimento das normas tenham sido suficientemente fortes para gerar negociações em relação aos mecanismos de controle.

\section{Abstract}

Composers of religious music have before them diverse possibilities of assimilation of musical elements in their creative process. The same applies to the selection of works by the interpreters. This paper analyzes the paradigms instituted by the motu proprio on the sacred music of Pius X, promulgated in 1903, and its reflexes in the practices of religious music in Brazil between 1903 and 1963. For this, we used the notions of habitus in Pierre Bourdieu, Weberian types of domination in Walter Buckley, and the pre-compositional model (MPC) in Sotuyo Blanco. The results point to the existence of an expectation of institutional control of the rational-legal type, including with censors agencies. Little compatible with the notions of habitus or MPC, this phenomenon demands the development of a specific concept, that of normative control of musical practices.

Keywords: Liturgical music in Roman Catholic Church. Motu proprio "Tra le Sollecitudini". Normative control of musical practices. Romanization.

\section{Resumen}

Los compositores de música religiosa tienen ante sí varias posibilidades de asimilación de elementos musicales en su proceso creativo. Lo mismo ocurre con la selección de obras por los intérpretes. Este trabajo analiza los paradigmas instituidos por el motu proprio sobre la música sacra de Pío $X$, promulgado en 1903, y sus reflejos en las prácticas de música religiosa en Brasil entre 1903 y 1963. Para ello, se recurre a las nociones de habitus, en Pierre Bourdieu, De los tipos weberianos de dominación, en Walter Buckley, y de modelo pre-composicional (MPC), en Sotuyo Blanco. Los resultados apuntan a la existencia de una expectativa de control institucional del tipo racional-legal, incluso con organismos censores. Poco compatible con las nociones de habitus o MPC, tal fenómeno demanda lo desarrollo de uno concepto específico, el de control normativo de las prácticas musicales.

Palabras clave: Control normativo de las prácticas musicales. Motu proprio "Tra le Sollecitudini". Música litúrgica en la Iglesia Católica Romana. Romanización.

\section{Notas}

1 SOBRE MÚSICA SACRA. Motu proprio Tra le sollecitudini. 22 nov. 1903. Texto em português. Disponível em: <http://www.vatican.va/holy_ father/pius_x/motu_proprio/documents/hf_p-x_motu-proprio_19031122_sollecitudini_po.html>. Acesso em 3 mai. 2009.

Id., $\$ 3^{\circ}$.

3 Quando as composições eram escritas a poucas vozes, o instrumento poderia completar a harmonia - formar acordes - desde que as notas musicais inseridas respeitassem o caráter de melodia vocal. Não havia, portanto, a inserção de ritmos no acompanhamento instrumental. 
4 O LIDADOR. Mandamentos da Hygiene. [Cidade de] Goyaz, p.3, 3 jun. 1909.

5 "Não negligencie o asseio pessoal, ou antes, não seja desasseado em coisa alguma. Da pequena moral, é a limpeza um dos mais importantes artigos. [...] Não negligencie os pequenos cabelos que saem do nariz e dos ouvidos. Os dentes, as unhas e a barba. Se usar esta última raspada, convém fazê-la todos os dias, a fim de não ter aparência de doente. Não limpe as unhas, os ouvidos, nem esgravate o nariz na presença de ninguém. O que é próprio do toillette não deve ser feito em público. Não pinte o cabelo, nem a barba: deixe isto para os fracos de espírito. Não use óleo ou pomada. Este costume foi geral outrora; mas hoje é considerado baixo. [...] Não toque tambor com os pés no assoalho, com os dedos na cadeira, mesa ou outro objeto. e... não esquipe com a perna. A disposição para fazer barulho é sinal de selvageria." O LIDADOR. Trajos e costumes. [Cidade de] Goyaz, 6 maio, p. 3, 6 mai. 1909.

6 CORREIO DO POVO. 1904. Musicas sacras. Florianópolis, 20 fev., p. 1. Registre-se aqui o agradecimento a Solange Scolaro e Marcos Holler pelo compartilhamento desta fonte digitalizada.

7 As missas devem ser compreendidas, neste período, como composições musicais a uma voz ou polifônicas sobre os textos do Kyrie (Ato penitencial), Gloria, Credo, Sanctus-Benedictus e Agnus Dei (Cordeiro de Deus). Não é raro, entretanto, que o Credo seja omitido - graças à dificuldade que a extensão de seu texto irregular gerava para os compositores -, sendo a composição moderna substituída, na liturgia, pelo canto gregoriano.

8 SOBRE MÚSICA SACRA, 1903, \$24.

9 CAMS-RJ. $1^{\circ}$ Índice das músicas examinadas para uso litúrgico pela Comissão Arquidiocesana de Música Sacra do Rio de Janeiro. Petrópolis: Vozes, 1946.

10 Os bispados encaminhavam questões ou solicitações específicas sobre aspectos litúrgicos e musicais e a Sagrada Congregação dos Ritos se posicionava a respeito, servindo a resposta como uma espécie de jurisprudência de valor vinculante para as demais dioceses.

11 Modos eclesiásticos e escalas são sequências de sons a partir das quais se estruturam as composições. Nestas sequências, os diferentes graus (notas musicais) possuem papeis estruturais distintos, que se refletem não apenas nas melodias, mas também na harmonização.

12 Notas repetidas - sem duração definida na partitura - sobre as quais os textos são declamados a uma ou mais vozes, como se ouve nas orações gregorianas dos padres - mesmo em língua vernácula - até o presente (rectus tonae).

\section{Referências}

BUCKLEY, W. A sociologia e a moderna teoria dos sistemas. São Paulo: Editora USP, 1971.

CANDAU, J. Memória e identidade. São Paulo: Contexto, 2011.

CHIAVENATO, I. Gestão de pessoas: o novo papel dos recursos humanos nas organizações. 2 . ed. Rio de Janeiro: Campus, 2005.

DUARTE, F. L. D. Música e Ultramontanismo: possíveis significados para as opções composicionais nas missas de Furio Franceschini. São Paulo: Cultura Acadêmica, 2012.

DUARTE, F. L.S. Resgates e abandonos do passado na prática musical litúrgica católica no Brasil entre os pontificados de Pio X e Bento XVI (1903-2013). 2016. Tese (Doutorado em Música) - Programa de Pós-Graduação em Música, Universidade Estadual Paulista, São Paulo, 2016.

DUFFY, E. Santos e pecadores: história dos papas. São Paulo: Cosac \& Naify, 1998.

GAETA, M. A. J. A Cultura clerical e a folia popular: estudo sobre o catolicismo brasileiro nos finais do século XIX e início do Século XX. Revista Brasileira de História, São Paulo: Anpuh, v. 17, n. 34, p. 183-202. 1997.

INAMA, G. B.; LESS, M. La musica ecclesiastica secondo la voluntá della chiesa: Istruzione per $i$ capi coro e per $i$ sacerdoti. Trento: Strad. Tip. G. B. Monauni, Ed., 1892.

LEHMANN, J. B. Harpa de Sião: coleção de cânticos sagrados para uma ou mais vozes com acompanhamento do harmônio ou do órgão. Juiz de Fora: Lar Católico, 1928.

LUHMANN, N. Social Systems. Stanford: Stanford University Press, 1995.

MONTERO, P. Tradição e modernidade: João Paulo II e o problema da cultura. Revista Brasileira de Ciências Sociais, São Paulo: Anpocs, v. 20, n. 7, p. 90-112, 1992. 
NOGUEIRA, M. A. Bourdieu E a educação. 2. ed. Belo Horizonte: Autêntica, 2006.

ORTIZ, R. A morte branca do feiticeiro negro: umbanda e sociedade brasileira. São Paulo: Brasiliense, 1999.

REALE, M. Lições preliminares de Direito. 25.ed. São Paulo, Saraiva, 2001.

RÖWER, B. A musica sacra segundo o motu-proprio de sua santidade Pio X. Petrópolis: Typ. Do Collegio S. José, 1907.

SCHUBERT, G. A música sacra no Rio de Janeiro em redor de 1910. In: COSTA, L. A. S. et al. Brasil 1900-1910. Rio de Janeiro: Biblioteca Nacional, 1980. p.11-45.

SOTUYO BLANCO, P. Modelos pré-composicionais nas lamentações de Jeremias no Brasil. 2003. Tese (Doutorado em Música). Programa de Pós-Graduação em Música, Universidade Federal da Bahia, Salvador, 2003.

WERNET, A. A igreja paulista no século XIX: a reforma de D. Antônio Joaquim de Melo (18511861). São Paulo, Ática: 1987. 